\title{
Diversity patterns, research trends and mismatches of the investigative efforts to amphibian conservation in Brazil
}

\author{
FELIPE S. CAMPOS ${ }^{1}$, DANIEL BRITO ${ }^{1,2}$ and MIRCO SOLÉ ${ }^{1}$ \\ ${ }^{1}$ Programa de Pós-Graduação em Ecologia e Conservação da Biodiversidade, \\ Universidade Estadual de Santa Cruz/ UESC, Rodovia Ilhéus-Itabuna, Km 16, 45662-000 Ilhéus, BA, Brasil \\ ${ }^{2}$ Programa de Pós-Graduação em Ecologia e Evolução, Universidade Federal de Goiás/ UFG, \\ Rodovia Goiânia-Nerópolis, Km 5, Caixa Postal 131, 74001-970 Goiânia, GO, Brasil
}

Manuscript received on April 7, 2014; accepted for publication on July 7, 2014

\begin{abstract}
The number of papers on biology of amphibians has increased in the recent years. A detailed overview of the publications on amphibians can be very useful in assessing the status of our knowledge about this taxonomic group. Due to the large number of articles published, we aimed to assess the scientific contribution of herpetological researches carried out between the years 2001 and 2010 on Brazilian amphibians, considering the diversity patterns, the threats and the research topics that have been published most often. We applied scientometric attention indexes in the reviewed studies from seven scientific databases. To examine the relationship between the numbers of species recorded locally and regionally at different spatial scales, we used an additive partitioning of diversity in three hierarchical levels (i.e., states, geographic regions and biomes). We evaluated 892 articles and 914 species, which showed that $65 \%$ of the total diversity of Brazilian amphibian species was represented by the beta diversity among the biomes. We identified many differences in the allocation of research efforts for taxonomic groups, threats categories, geographic regions, and research topics, highlighting the main research trends conducted and the priority themes for investigation of further papers on Brazilian amphibians.
\end{abstract}

Key words: amphibians, scientometry, attention index, additive diversity partitioning, temporal trend.

\section{INTRODUCTION}

The causes of amphibian populations declining vary from region to region and can show synergistic interactions between more than one threat factor (Davidson and Knapp 2007, Blaustein et al. 2010). However, habitat alteration accounts for more declines than any other factor (e.g., Beebee and Griffiths 2005, IUCN et al. 2006, Halliday 2008, Becker et al. 2010).

Correspondence to: Mirco Solé

E-mail:msole@uesc.br
There is a substantial amount of evidence of amphibian declines around the world (Stuart et al. 2004). Yet, strategies to solve this problem have been developed mainly by scientists from the United States, Western Europe and Australia (Houlahan et al. 2000, Young et al. 2001, Brito 2008). Some regions have developed strategies for studying the problem of amphibian declines and have amassed useful information about potential causes (e.g., Europe, Araújo et al. 2006, Australia, Hero et al. 2006, United States, Adams et al. 2013). 
There is also evidence for amphibian declines in different regions in Brazil (e.g., Heyer et al. 1988, Weygoldt 1989, Bertoluci and Heyer 1995, Guix et al. 1998, Pombal and Haddad 1999, Izecksohn and Carvalho-e-Silva 2001, Eterovick et al. 2005). As in other Latin American countries, understanding and preventing the decline of populations of amphibians is hampered by a lack of information and appropriate governmental policies to address this issue (Juncá 2001, Silvano and Segalla 2005).

Compiling data about species distribution ranges, is an important step in planning conservation actions (Hurlbert and Jetz 2007), which has been shown in recent studies on Brazilian amphibian communities (e.g., Trindade-Filho et al. 2012, Verdade et al. 2012, Morais et al. 2013). The greatest diversity of amphibians in the world is recorded in Brazil, with 946 described species (Segalla et al. 2012). However, 33 amphibian species distributed in Brazil are listed in the IUCN Red List, as being 17 vulnerable, 7 endangered, and 9 critically endangered (IUCN 2012). Despite this, the knowledge generated about biogeography and taxonomy of Brazilian amphibians is still fairly recent, because several species are often revalidated, and mainly because every year new species have been discovered (Silvano and Segalla 2005, Toledo and Batista 2012).

Even though the number of publications dedicated to the conservation of amphibians has increased in recent years, most conservation strategies for the communities of amphibians are still directed at areas of low biodiversity and with non-endangered species (Brito 2008). An analysis of the national and international conservation measures presented in journals published in recent years can indirectly provide an index of attention to a given taxonomic group (Brito 2008). Therefore, an overview of the recent publications on amphibians in Brazil can be considered a good sample of the current research conducted on the conservation status of these species.
In this context, we aimed to evaluate the state of knowledge of the herpetological surveys conducted over the last decade on the Brazilian amphibians. On the assumption that the number of publications can be an adequate measurement of scientific productivity, we tested the following hypotheses: (1) there are large differences between the numbers of articles published in relation to taxonomic groups and threat categories, (2) the allocation of research efforts is associated with the species richness of the Brazilian biomes, (3) there is a progressive increase in the number of articles published each year on the Brazilian amphibians, (4) Brazil is the most frequent country among the affiliation of the authors of the papers published about Brazilian amphibians, and (5) there is a temporal variation in the research topics among the articles on Brazilian amphibians. Based on the data assessed, we established diversity patterns, attention indexes and the main research trends of the published studies, thus predicting the priority themes for investigation of further studies.

\section{MATERIALS AND METHODS}

\section{DATA ACQUISITION}

We used scientometric techniques and multivariate analyses from the collection of information relating to the publications of seven international databases (Web of Science, ScienceDirect, Scopus, Wiley Online Library, BioOne, Scielo, and DOAJ). In these analyses, we only included papers published between 2001 and 2010 that featured the terms "Amphibia*", "Anura*", "Caudata", and/or "Gymnophiona", along with the word "Brasil" or "Brazil" in their title, abstract, or keywords.

For each selected study, we identified the year of publication, the nationality of the authors, the place of the work, the keywords, the main research topic, the name of the journal and its impact factor, the population trend and the threat category of the species mentioned, according to the IUCN 
Red List of Threatened Species categories (i.e., Critically Endangered - CR, Endangered - EN, and Vulnerable - VU, IUCN 2012). Species classified as Near Threatened - NT were excluded from the analysis of threat category, because we adopted only the criteria prepared by the IUCN Species Survival Commission (IUCN 2001), which refers to term "Threatened" only in the categories CR, EN and VU.

\section{DATA ANALYSIS}

In accordance to Brito (2008), we generated three scientometric attention indexes among the studies analyzed. A taxonomic attention index (AI-taxon) was obtained for the families of amphibians presented in each study, dividing the number of articles related to each family by the number of species from the same family, thus providing a general framework of attention to the families of Brazilian amphibians. A threat attention index (AI-threat) was obtained dividing the number of articles dedicated to threatened species by the number of threatened species in each family evaluated. A biogeographic attention index (AIbiogeog) was calculated for the different Brazilian biomes, dividing the number of articles related to each biome by the number of amphibian species recorded per biome. These data were obtained according to the information from articles assessed and from reviews of distribution maps from the IUCN database (IUCN 2012). In addition, we applied a simple linear regression analysis among the number of articles published and the number of species in each group assessed, using the software Ecosim 7.72 (Gotelli and Entsminger 2005). The classification of biomes follows that of the Brazilian Institute of Geography and Statistics (IBGE 2004), and the nomenclature of amphibian species follows Frost (2014).

We analyzed the critical mass corresponding to the geographic regions of each biome from Brazil from the database of the National Council for Scientific and Technological Development (CNPq
2010). We used regression analysis to explore the relationships between the numbers of researchers that have the term "amphibia" in their curriculums with the numbers of published articles on amphibians in each region considered. This analysis was generated by the software Ecosim 7.72 (Gotelli and Entsminger 2005), providing correlation data and probability of significance of the variables analyzed, according to a significance level of $5 \%$.

The compilation of species richness assessed was obtained through a joint evaluation of the IUCN database (IUCN 2012) and the papers considered in this study. To examine the relationships between the numbers of species recorded locally and regionally at different spatial scales, we used an additive partitioning of diversity in three hierarchical levels (i.e., states, geographic regions and biomes). For each spatial level a value of alpha and beta diversity was associated. Thus, $\alpha 1$ and $\beta 1$ represented the alpha and beta diversity in the lower level (i.e., states), so that $\beta 2$ and $\beta 3$ corresponded to beta diversity in the two subsequent levels (i.e., geographical regions and biomes). The statistical significance of each component was measured using a null model, as proposed by Crist et al. (2003). All analyses for the additive partitioning of diversity were performed by the R software (R Development Core Team 2009), using the algorithms "boot" and "mass" through the adipart function in the $\mathrm{R}$ package vegan (Oksanen et al. 2009).

To assess the similarity in the species composition among the Brazilian biomes, we used a hierarchical cluster analysis based on the Sorensen coefficient (Magurran 2004), reflecting the biogeographic patterns in the structure of amphibian communities in Brazil. This analysis was conducted through the unweighted pair group with arithmetic mean method (UPGMA), performed by the software MVSP (Kovach 2004).

From the number of papers published per year it was possible to estimate the temporal trends relative to the number of studies on amphibians in 
Brazil. To assess the contribution of new species to the advances in the basic taxonomic knowledge of the Brazilian amphibians, we superimposed the number of new species recorded each year on the total number of published articles.

To provide the number of published articles according to each research topic studied, we classified the assessed papers into 15 categories of subjects, so that each paper was placed under only one category (i.e., Taxonomy and systematics, Behavioral ecology, Community ecology, Trophic ecology, Reproductive biology, Morphology, Geographic distribution, Conservation biology, Genetic, Phylogeny, Species inventories, Parasitology, Pharmacology, Population ecology, or Physiology).

\section{RESULTS}

We found 892 articles focusing on amphibian species from Brazil in the period analyzed (Table I). In total, we assessed 914 species of amphibians distributed in Brazil. The AI-taxon (taxon-based attention index) showed that Ranidae was the family that received most of the attention among the researchers, unlike the Microhylidae family, which was less studied according to this index (Table I). In general, the values presented by the AI-taxon were low, mainly due to the relatively small number of articles published in relation to the large number of species of each family assessed, although there is a high correlation between these numbers $\left(\mathrm{r}^{2}=\right.$ $0.97, \mathrm{p}<0.01)$. For the threatened species, there was not a strong correlation between the number of articles published and the number of species in each family $\left(r^{2}=0.54, p=0.06\right)$, where the AIthreat was greater to Leptodactylidae and smaller to Bufonidae. Nevertheless, about $16 \%$ of published articles focused on the study of threatened species, which corresponds to only $3.6 \%$ of the pool of species assessed (see Table I).

Most of the species cited in the assessed articles showed unknown population trends. Although 804 species of amphibians with geographical distribution in Brazil have been cited in articles published between 2001 and 2010, only $0.6 \%$ had an increasing population trend (Table II). However, about $25 \%$ of species assessed in different threat categories showed a declining population trend, among which only $15 \%$ was effectively considered as threatened (i.e., species categorized as VU, EN or CR). The high proportion of threatened species with declining population trends indicates that the real number of threatened amphibian species in Brazil may be higher than that estimated by the IUCN criteria (see Table II).

The AI-biogeog indicated that the biomes that received the most attention from the researchers were the Cerrado and the Atlantic Forest (Fig. 1). However, the Cerrado presented a number of species much smaller than the Atlantic Forest (i.e., 188 compared with 504 species), which explains the difference between the values stated for both biomes (Fig. 1). In addition, this fact can also be explained by the critical mass corresponding to the regions of each biome. There was a high correlation between the relative number of researchers who presented the term "amphibia" on their curriculums with the number of articles published on amphibians in each geographic region of Brazil $\left(\mathrm{r}^{2}=0.97\right.$, $p=0.04)$. Therefore, the profile of the values of the AI-biogeog was low when compared to the other biomes evaluated (Fig. 1).

The additive partitioning of diversity indicated that the proportion of the data observed for the alpha and beta diversity in the three scales sampled (i.e., states, geographic regions and biomes) basically did not differ from that obtained by random chance (Fig. 2). However, the null model showed a small increase of the expected diversity among biomes when compared to the observed diversity in this scale. The remaining values expected in a random distribution of individuals were lower than those shown by the observed diversity (Fig. 2). The values of the partitioning of diversity showed an apparent complementarity among the scales sampled. 
TABLE I

Total number of species, threatened species, published articles, published articles dedicated to threatened species, AI-taxon and AIthreat for each amphibian family recorded in Brazil.

\begin{tabular}{|c|c|c|c|c|c|c|}
\hline Order / Family & $\begin{array}{c}\mathrm{N} \text { of } \\
\text { species }\end{array}$ & $\begin{array}{c}\mathrm{N} \text { of threatened } \\
\text { species }\end{array}$ & $\begin{array}{c}\mathrm{N} \text { of } \\
\text { articles }\end{array}$ & $\begin{array}{c}\mathrm{N} \text { of articles on } \\
\text { threatened species }\end{array}$ & AI taxon & AI threat \\
\hline \multicolumn{7}{|l|}{ Order Anura } \\
\hline Family Allophrynidae & 1 & 0 & 2 & 0 & 2.00 & - \\
\hline Family Aromobatidae & 22 & 3 & 19 & 2 & 0.86 & 0.67 \\
\hline Family Brachycephalidae & 48 & 0 & 24 & 0 & 0.50 & - \\
\hline Family Bufonidae & 70 & 8 & 82 & 2 & 1.17 & 0.25 \\
\hline Family Centrolenidae & 11 & 0 & 6 & 0 & 0.55 & - \\
\hline Family Ceratophryidae & 5 & 0 & 2 & 0 & 0.40 & - \\
\hline Family Craugastoridae & 2 & 0 & 1 & 0 & 0.50 & - \\
\hline Family Cycloramphidae & 69 & 5 & 30 & 4 & 0.43 & 0.80 \\
\hline Family Dendrobatidae & 18 & 0 & 14 & 0 & 0.78 & - \\
\hline Family Eleutherodactylidae & 6 & 2 & 1 & 1 & 0.17 & 0.50 \\
\hline Family Hemiphractidae & 16 & 1 & 4 & 0 & 0.25 & - \\
\hline Family Hylidae & 350 & 7 & 241 & 3 & 0.69 & 0.43 \\
\hline Family Hylodidae & 42 & 0 & 28 & 0 & 0.67 & - \\
\hline Family Leptodactylidae & 138 & 2 & 115 & 3 & 0.83 & 1.50 \\
\hline Family Microhylidae & 39 & 2 & 6 & 0 & 0.15 & - \\
\hline Family Pipidae & 4 & 0 & 1 & 0 & 0.25 & - \\
\hline Family Ranidae & 2 & 0 & 23 & 0 & 11.50 & - \\
\hline Family Strabomantidae & 42 & 3 & 9 & 2 & 0.21 & 0.67 \\
\hline \multicolumn{7}{|l|}{ Order Caudata } \\
\hline Family Plethodontidae & 1 & 0 & 2 & 0 & 2.00 & - \\
\hline \multicolumn{7}{|l|}{ Order Gymnophiona } \\
\hline Family Caeciliidae & 26 & 0 & 8 & 0 & 0.31 & - \\
\hline Family Rhinatrematidae & 1 & 0 & 1 & 0 & 0.50 & - \\
\hline General & - & - & 273 & 130 & - & - \\
\hline Total & 914 & 33 & 892 & 147 & - & - \\
\hline
\end{tabular}

TABLE II

Relative number of species listed by threat category and population trend $(\mathrm{N}=\mathbf{8 0 4})$, according to the IUCN Red List categories (i.e., NE: Not Evaluated, LC: Least Concern, DD: Data Deficient, NT: Near Threatened, VU: Vulnerable, EN: Endangered, CR: Critically endangered, EX: Extinct).

\begin{tabular}{cccccccccc}
\hline \multirow{2}{*}{ Population trend } & \multicolumn{8}{c}{ Threat categories } & \multirow{2}{*}{$\%$} \\
\cline { 2 - 8 } & NE & LC & DD & NT & VU & EN & CR & EX & \\
\hline Unknown & 68 & 65 & 166 & 1 & 2 & 0 & 2 & 1 & 38.0 \\
Declining & 0 & 129 & 34 & 19 & 10 & 7 & 6 & 0 & 25.4 \\
Stable & 0 & 278 & 4 & 3 & 3 & 0 & 1 & 0 & 36.0 \\
Increasing & 0 & 5 & 0 & 0 & 0 & 0 & 0 & 0 & 0.6 \\
\hline$\%$ & 8.5 & 59.3 & 25.4 & 2.9 & 1.8 & 0.9 & 1.1 & 0.1 & 100 \\
\hline
\end{tabular}




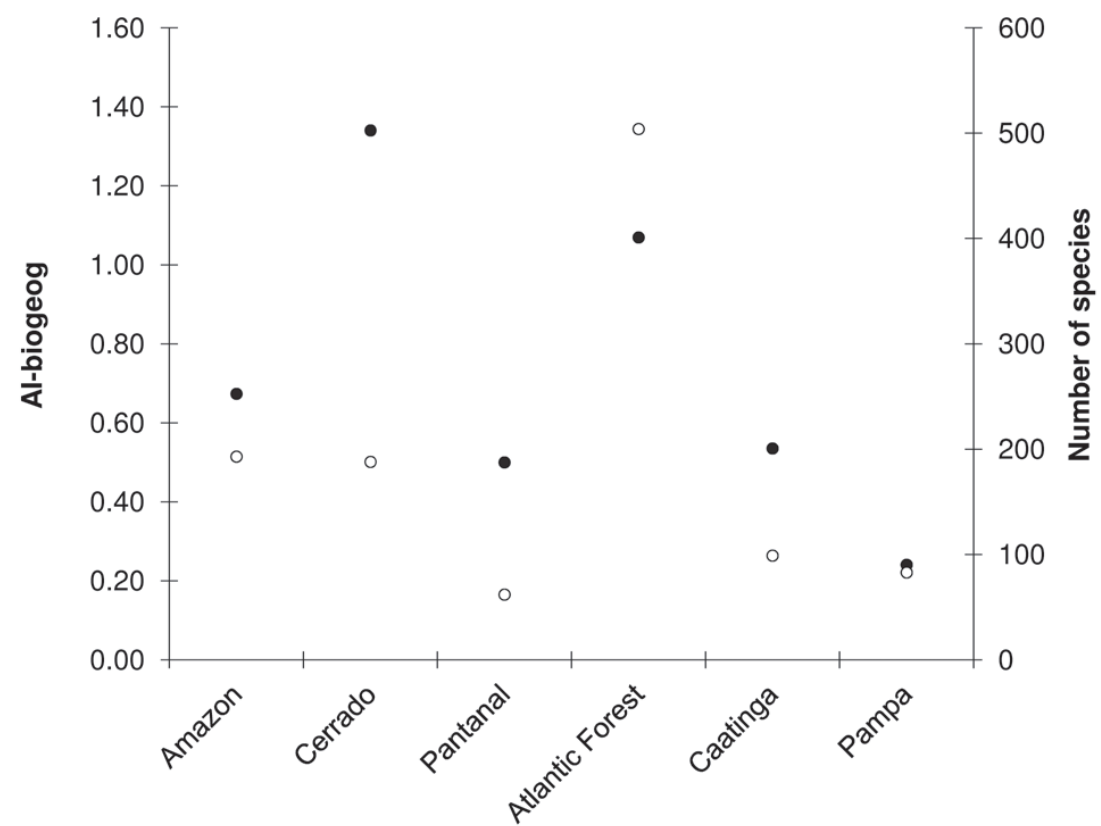

Figure 1 - Biogeographic attention index (black dots) and total number of amphibian species recorded (white dots) for each biome in Brazil.

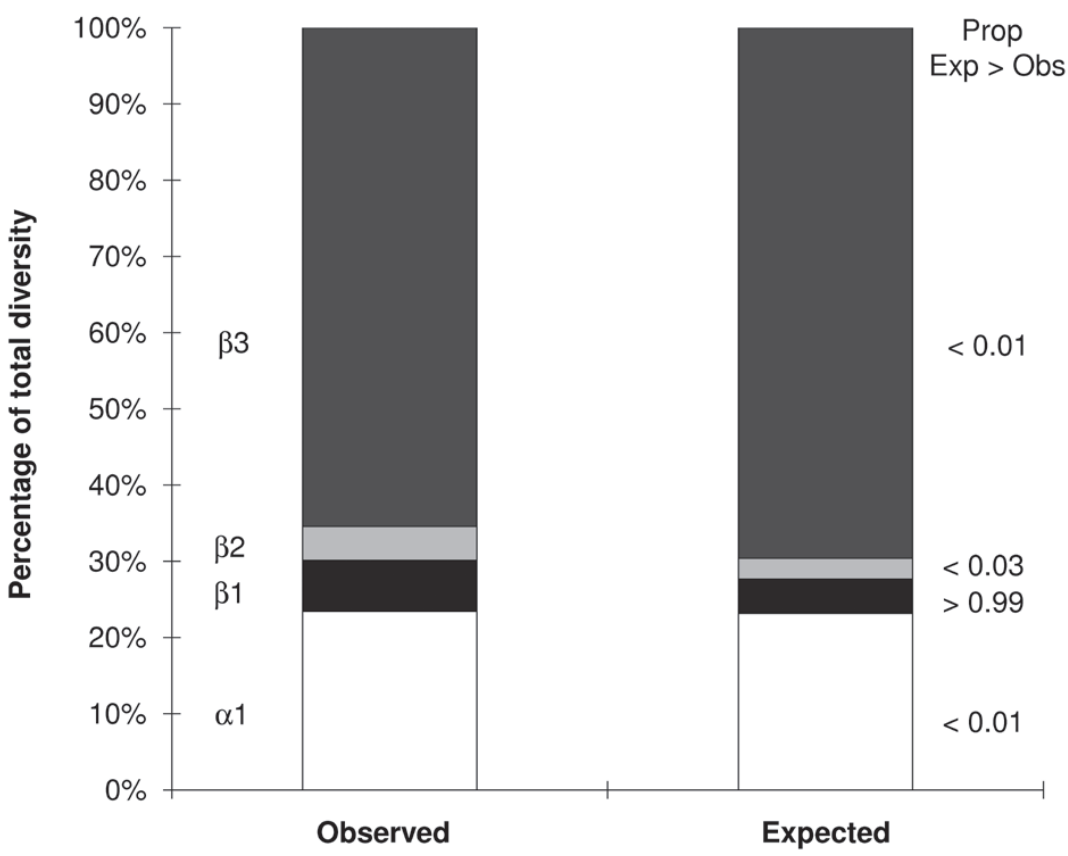

Figure 2 - Additive partitioning of diversity of amphibians recorded in Brazil in three spatial scales. The values on the right refer to the proportion in which the number of times the value expected by the null model (Exp) was higher than that value observed (Obs). The percentage values correspond to the proportion of the number of species recorded in each spatial level, being $\alpha 1$ and $\beta 1$ the alpha and beta diversity in the lowest level (i.e., states), and $\beta 2$ and $\beta 3$, the beta diversity in the two subsequent levels (i.e., geographical regions and biomes). 
Nevertheless, the results showed that $65 \%$ of the total species diversity of Brazilian amphibians was represented by the beta diversity among the biomes of the country (Fig. 2).

The biogeographic patterns in the structure of amphibian communities from Brazil reflected by the proportion of similarity of species among the biomes were highly variable, even for neighboring biomes (Fig. 3). The greatest proportion of similarity, indicated by Sorensen's coefficient, was between the Cerrado and the Caatinga, with $49 \%$ of similarity. In general, the values obtained were low, not exceeding $50 \%$ of similarity, implying a high disparity in the amphibian species composition among the different Brazilian biomes (Fig. 3), which confirms its high beta diversity pattern.

The increase in the number of studies conducted on amphibians between 2001 and 2010 allowed an addition of 132 new species in Brazil (Fig. 4), among which $60 \%$ are distributed in Atlantic Forest, 22\% in Cerrado, $12 \%$ in Amazon, 3\% in Caatinga, $2 \%$ in Pantanal and $1 \%$ in Pampa. The affiliation of the authors of the articles analyzed indicated a total of 19 countries that contributed to the publications of the last decade (Fig. 5), but were mostly conducted through partnerships with Brazilian researchers, reflecting the enormous diversity of species found in Brazil and its broad potential for new discoveries regarding the biology of Neotropical amphibians. We identified four languages among the articles assessed, corresponding to 763 publications in English, 127 in Portuguese, one in German and one in Spanish.

The articles that presented new data on geographic distribution of species showed 64 new records of the Brazilian amphibians (Fig. 6). However, taxonomy and systematics were the research topics preferred by the authors considered, representing about $20 \%$ of studies, indicating a progressive increase of articles related to the taxonomic reviews and descriptions of new species over the last decade. In contrast, physiology, population ecology, and pharmacology, were the topics least investigated, with about $3 \%$ of studies on each topic (Fig. 6).

\section{DISCUSSION}

The increasing number of publications on amphibians from Brazil can be regarded as a result of the progressive increase in the number of researchers

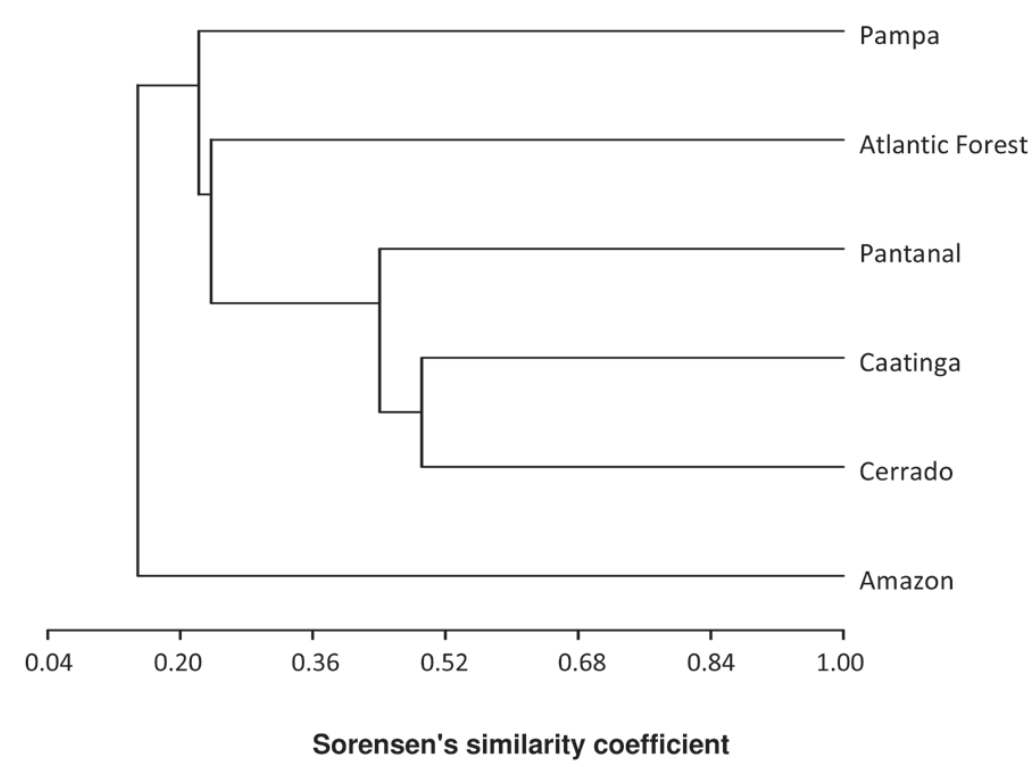

Figure 3 - Dendrogram of similarity of amphibian species recorded among the Brazilian biomes. 


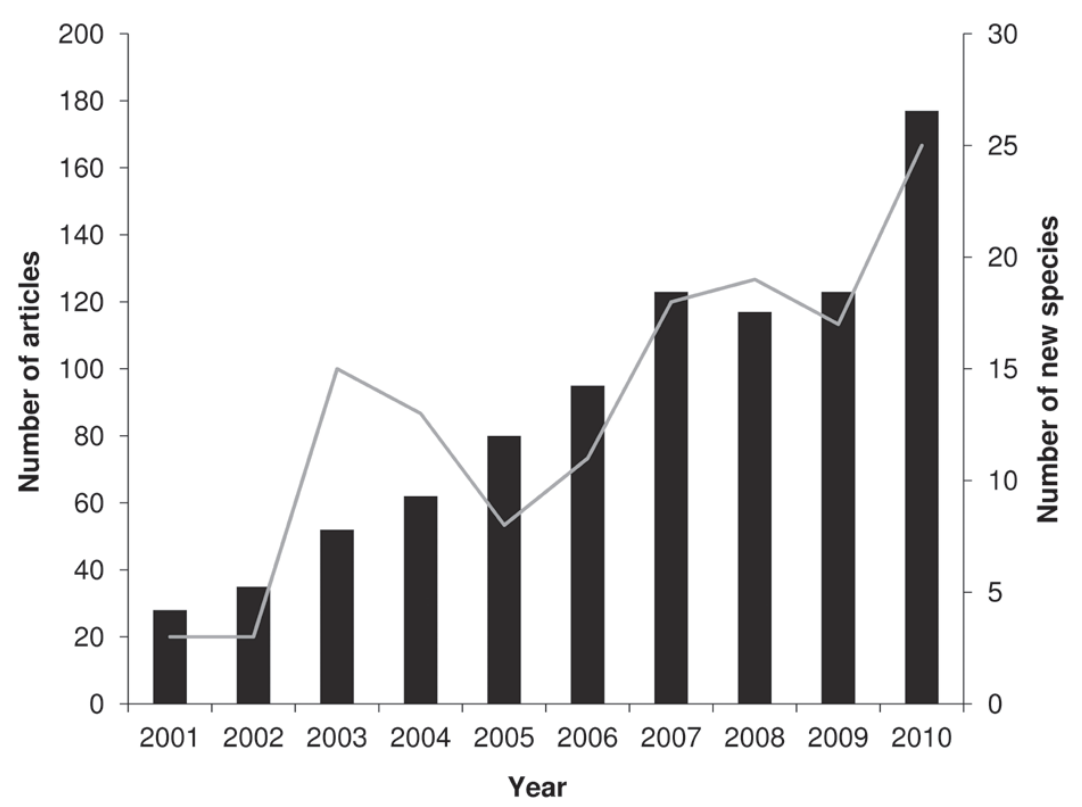

Figure 4 - Number of published articles on amphibians (bars) and number of new species discovered (line) between 2001 and 2010 in Brazil.

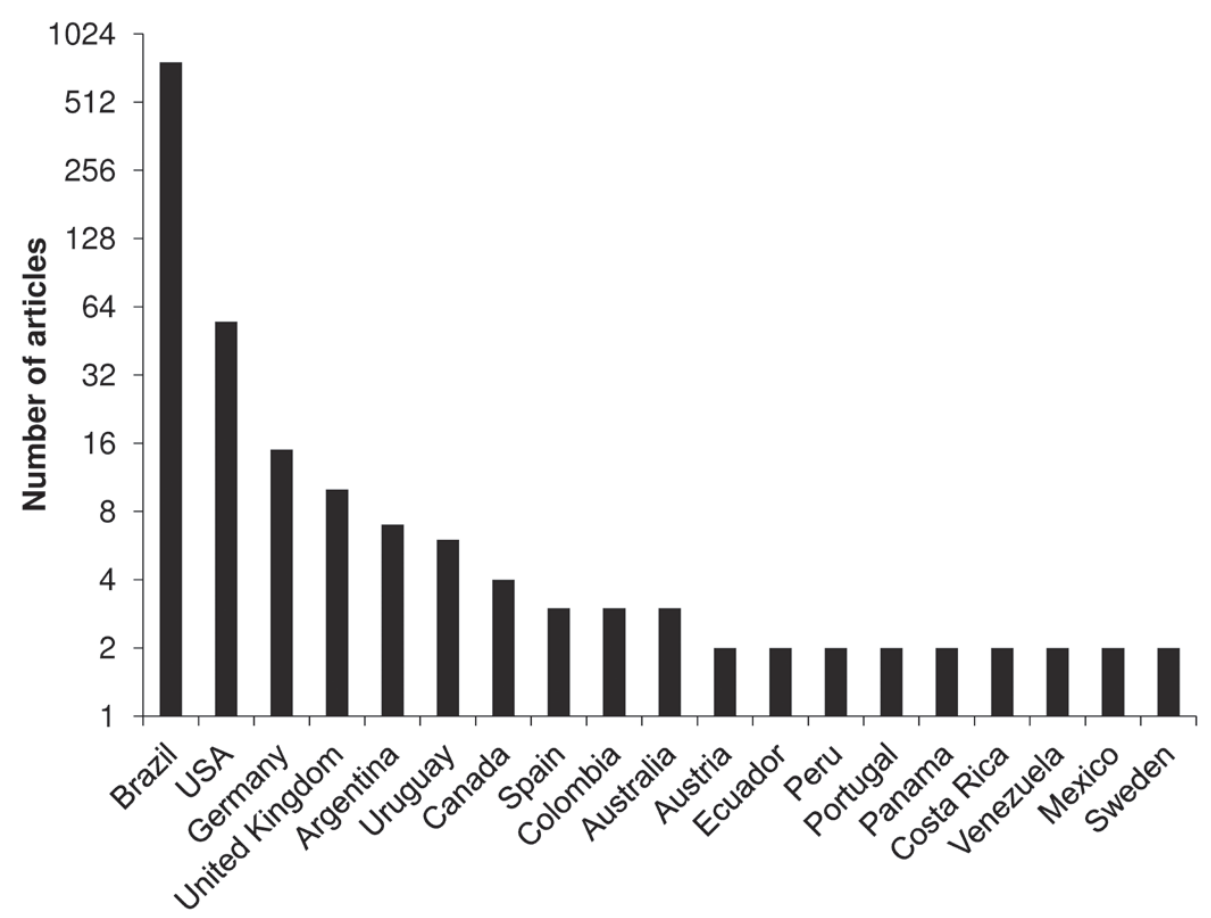

Figure 5 - Total number of articles published between 2001 and 2010 on amphibians from Brazil $(\mathrm{N}=892)$ in relation to the country of affiliation of the authors.

interested in Brazilian herpetology. Important trends and biases were observed in relation to the study of Brazilian amphibians. The results showed that there are many differences in the allocation of research efforts for different taxonomic groups and geographic regions, as well as for some research topics. 


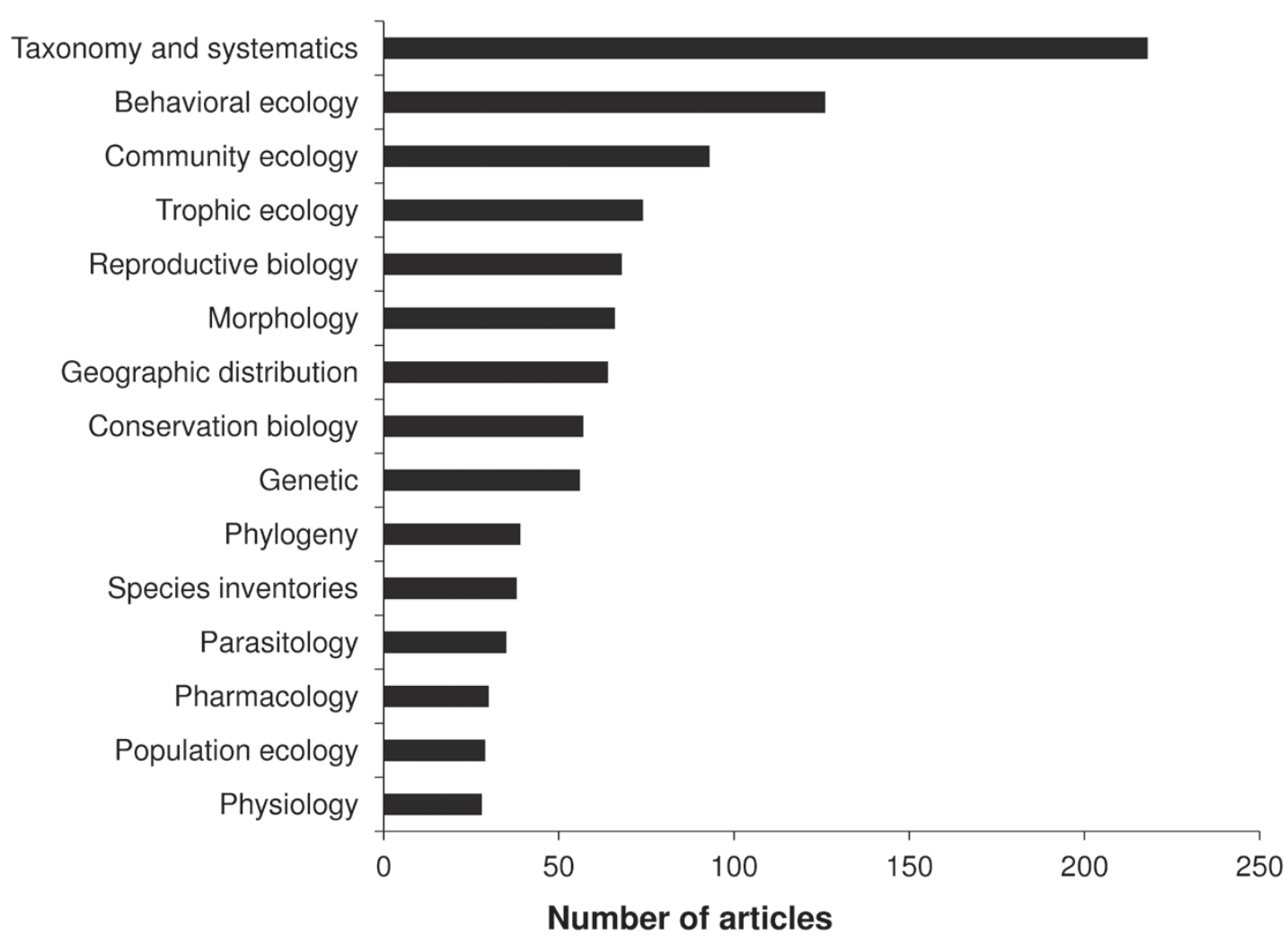

Figure 6 - Total number of articles published between 2001 and 2010 on amphibians from Brazil $(\mathrm{N}=892)$ according to their respective research topics.

Some unexpected trends were observed in the attention given to different families of amphibians. The Ranidae family, which is represented by only two species in Brazil, one having been introduced (Lithobates catesbeianus) and the other one being native (L. palmipes), received the highest values on the AI-taxon, possibly because of their economic values. However, the American bullfrog (L. catesbeianus) is considered one of the most harmful invasive species to native amphibian communities (Lowe et al. 2000, Giovanelli et al. 2008). In Brazil, introductions of this species have occurred since 1930 in associations with the advancement of aquaculture (Fontanello and Ferreira 2007). In the last decade, the species was recorded in the field throughout various localities of south, central and southeast of the country (Both et al. 2011), especially in large areas of the Atlantic Forest (Dixo and Verdade 2006, Conte and Rossa-
Feres 2006, Both et al. 2011). It remains unknown to what extent this species contributes to the decline of population of some Brazilian amphibians (Young et al. 2001, Silvano and Segalla 2005). However, already there are some studies about the impacts of the American bullfrog in Brazil, such as competition for microhabitat, changes in acoustic niches, and imbalance among predator-prey relationships in native species (e.g., Silva et al. 2011, Boelter et al. 2012, Both and Grant 2012).

More than 2,000 amphibian species are listed as threatened by extinction, to the extent that amphibians are the most threatened vertebrate group in the world (Stuart et al. 2004). Although many reductions and extinctions of amphibians have occurred due to the habitat loss, some unidentified processes still threaten $48 \%$ of amphibian species arround the world (Stuart et al. 2004). This lack of knowledge seriously impairs our ability to plan 
conservation actions to reverse these trends (Brito 2008). Our results showed that the level of threat to amphibians in Brazil still remains underestimated due to the lack of knowledge on approximately $25 \%$ of the species, which are classified as "Data Deficient" (DD). This trend remained the same when compared to a global scale in relation to amphibians worldwide (IUCN 2012). According to the Global Amphibian Assessment (IUCN et al. 2006), the real number of threatened and extinct species of amphibians can be much larger than currently acknowledged.

According to the relationship between the numbers of species per area, the Atlantic Forest is considered the leader biome in amphibian diversity in Brazil, accounting for about $50 \%$ of the total richness of amphibian species of the country (Conservation International et al. 2000, Silvano and Segalla 2005, Haddad et al. 2008). However, the high concentration of amphibian researchers in the southeastern region seems to be the main reason for the high concentration of studies focused in the Atlantic Forest, which can also be applied to the Cerrado. Unlike what occurs in the Brazilian Amazon, where information on the diversity of amphibians is fragmented and not readily available in the scientific literature (Azevedo-Ramos and Galatti 2002). This lack of information is especially problematic for salamanders and caecilians (Gower and Wilkinson 2005). Moreover, the taxonomic uncertainty applied to various groups of Amazonian amphibians makes this region worthy of further attention among the researchers (Caldwell 1996, Azevedo-Ramos and Galatti 2002). To improve this condition, some research groups need to acquire financial funds for applied studies aimed at understanding the basic knowledge of Amazonian herpetofauna, which despite having high species richness, still remains poorly studied.

The increased concern of researchers with the Brazilian amphibians in the last decade was highlighted by the difference among the numbers of published articles over the years 2001 and 2010, which presented 28 and 177 papers respectively. This probably occurred due to amphibians having been widely promoted as indicators of environmental quality (Lebboroni et al. 2006, Sewell and Griffiths 2009), which provides them with a special attention to conservation programs. In addition, amphibians are important components of many types of ecosystems, playing a key role in the dynamics between predators and prey (Blaustein et al. 1994). However, in comparison with other groups of vertebrates, such as birds and mammals, amphibians are still largely unknown (Brito 2008, Halliday 2008). This ignorance about amphibians is reflected in the high rates at which new species are being discovered and described. Birds and mammals have been considered traditionally more charismatic than amphibians (Brito 2008). Thus, there is a need to develop creative approaches to value this group. For example, such approaches could consist in promoting some amphibian species as charismatic through research projects linked to the media.

It is of paramount importance for the Brazilian herpetologists to publish the results of their research, because most of the surveys conducted in the tropics are not made by local scientists, but mainly by researchers from high-income countries (Fazey et al. 2005). A review conducted on three of the most important international conservation biology journals (i.e., Conservation Biology, Biological Conservation, and Biodiversity and Conservation) showed that $28 \%$ of studies published were from lower-income countries and only $15 \%$ of all assessed articles had primary authors from these nations (Fazey et al. 2005). However, our results about the affiliation of the authors showed that most of the published studies on amphibians from Brazil in the last decade were conducted by local researchers (i.e., $85 \%$ of the total published articles). This high number of publications by Brazilian authors may have been influenced by the growth of local 
investment in research infrastructure background in the recent years. According to King (2004), one measure of a nation's knowledge base is its output of $\mathrm{PhD}$ students, which is directly associated with the the growth of infrastructure investment. The science budget allocated in Brazil rose from US\$575 million in 2002 to over US\$3.3 billion in 2010 (Massarani 2013). Consequently, the number of $\mathrm{PhD}$ researchers trained in Brazil rose from 26,000 in 2001 to approximately 53,000 in 2010, thus only in 2010, more than 12,000 researchers were titrated as $\mathrm{PhD}$ in Brazilian postgraduate programs (MCT 2010).

Even though there is an constant increase in the number of $\mathrm{PhD}$ researchers in Brazil, this is still not enough to solve the biodiversity conservation demand in the country (Lawler et al. 2006), which is even more relevant in the case of amphibians (Urbina-Cardona 2008). Brazilian specialists agree that local amphibian species richness, taxonomy, geographic ranges, natural history and population status are vastly understudied in our country (Pimenta et al. 2005, Silvano and Segalla 2005, Verdade et al. 2012). Our results showed that research biases were detected for amphibian species that are more common and more widely distributed, as well as the trends observed at a global scale by Brito (2008), which showed that most amphibian conservation actions are directed at areas with non-threatened species. According to Schiesari et al. (2007), these biases when present, may reflect important consequences for the amphibian conservation in general or declining populations in particular. Particularly for amphibians, the intensity of threat may be inversely related to the abundance or geographic range of a species (Schiesari et al. 2007), so that many cases associated with declining populations were recorded at long distances from the research centers or in areas with little investment in science and technology (King 2004).

Amphibians are declining practically the entire world, but the lack of long-term regional data hinders the identification of their possible causes, thus hampering the establishment of conservation efforts (Stuart et al. 2004, Nystrom et al. 2007). Although the number of articles devoted to amphibians in Brazil has increased in recent years, there is still a great need for an increase in the number of articles focusing on the conservation of amphibians, especially with regards to threatened species, population dynamics and interspecific relations. Even in fragmented landscapes, we still have time to save some critical habitats for the conservation of species through systematic conservation planning (see Margules and Pressey 2000, Margules and Sarkar 2007, Diniz-Filho et al. 2007, Loyola et al. 2008, Sarkar and Illoldi-Rangel 2010). In addition, we must set priorities to assess whether the current distribution of protected areas include the geographic ranges of amphibian species that are conservation targets in Brazil. However, the selection criteria analyzed must be complemented with social participation, which includes decision makers to promote and understand the socio-economic related issues. Thus the priorization of conservation sites and research topics about Brazilian amphibians would possible at regional levels.

\section{ACKNOWLEDGMENTS}

We thank the structural support of the State University of Santa Cruz (UESC), Brazil. We are also grateful to D. Faria, S. Azzopardi, E. Muths, and two anonymous reviewers for their comments and suggestions to the manuscript. This study was funded by the Coordenação de Aperfeiçoamento de Pessoal de Nível Superior (CAPES), Brazil (Project \# 28007018011P9).

\section{RESUMO}

O número de artigos sobre biologia de anfíbios tem aumentado nos últimos anos. Um panorama detalhado destas publicações pode ser bastante útil na avaliação do estado do nosso conhecimento sobre este grupo taxonômico. Em função do grande número de artigos 
publicados no Brasil a cada ano, nós avaliamos a contribuição das pesquisas herpetológicas realizadas entre os anos de 2001 e 2010 no que diz respeito aos anfíbios brasileiros, consideirando os padrões de diversidade, as ameaças e os temas de investigação que mais têm sido publicados. Índices de atenção cienciométricos foram aplicados nos estudos analisados a partir de sete bancos de dados. Para ponderar a relação entre o número de espécies registradas localmente e regionalmente em diferentes escalas espaciais, nós utilizamos análises de partição aditiva da diversidade em três níveis hierárquicos (i.e., estados, regiões geográficas e biomas). Nós avaliamos 892 artigos e 914 espécies, o que mostrou que $65 \%$ do total da diversidade de espécies de anfíbios brasileiros foi representada pela beta diversidade entre os biomas. Nós identificamos muitas diferenças na alocação de esforços de pesquisa para grupos taxonômicos, categorias ameaças, regiões geográficas e tópicos de pesquisa, destacando as principais tendências de investigação desenvolvidas e os temas prioritários para a investigação de novos trabalhos sobre os anfíbios brasileiros.

Palavras-chave: anfíbios, cienciometria, índice de atenção, partição aditiva de diversidade, tendência temporal.

\section{REFERENCES}

ADAMS MJ ET AL. 2013. Trends in amphibian occupancy in the United States. PLoS ONE 8: e64347.

Araújo MB, Thuiller W AND Pearson RG. 2006. Climate warming and the decline of amphibians and reptiles in Europe. J Biogeogr 33: 1712-1728.

Azevedo-Ramos C AND Galatti U. 2002. Patterns of amphibian diversity in Brazilian Amazônia: conservation implications. Biol Conserv 103: 103-111.

BeCKER CG, FonsECA CR, HADDAD CFB AND PRADO PI. 2010. Habitat Split as a Cause of Local Population Declines of Amphibians with Aquatic Larvae. Conserv Biol 24: 287-294.

BEEBEE TJC AND GRIFFITHS RA. 2005. The amphibian decline crisis: a watershed in conservation biology? Biol Conserv 125: 271-285.

BERTOLUCI J AND HEYER RW. 1995. Boracéia Update. Froglog: Newsletter of the IUCN/SSC Amphibian Specialist Group 14: $2-3$

Blaustein AR, WAKe DB AND Sousa WP. 1994. Amphibian declines: judging stability, persistence, and susceptibility of populations to local and global extinctions. Conserv Biol 8: 60-71.
Blaustein AR, WALls SC, BANCROFT BA, LAWLER JJ, SEARLE CL AND GERVASI SS. 2010. Direct and Indirect Effects of Climate Change on Amphibian Populations. Diversity 2: 281-313.

BoELTER RA, KAEFER IL, BOTH C AND CECHIN SZ. 2012. Invasive bullfrogs as predators in a Neotropical assemblage: What frog species do they eat? Anim Biol 62: 397-408.

Both C AND GRANT T. 2012. Biological invasions and the acoustic niche: the effect of bullfrog calls on the acoustic signals of white-banded tree frogs. Biol Lett 8: 714-716.

BOTH C, LINGNAU R, SANTOS-JR A, MADALOZZO B, LIMALPAND GRANT T. 2011. Widespread Occurrence of the American Bullfrog, Lithobates catesbeianus (Shaw, 1802) (Anura: Ranidae), in Brazil. South Am J Herpetol 6: 127-134.

BRITO D. 2008. Amphibian conservation: Are we on the right track? Biol Conserv 141: 2912-2917.

CALDWELL JP. 1996. Diversity of Amazonian anurans: the role of systematics and phylogeny in identifying macroecological and evolutionary patterns. In: GIBSON AC (Ed), Neotropical Biodiversity and Conservation. Los Angeles: University of California, Mildred E. Mathias Botanical Garden, USA, p. 73-88.

CNPq. 2010. Painel Lattes: Distribuição Geográfica. Conselho Nacional de Desenvolvimento Científico e Tecnológico. Available at: http://lattes.cnpq.br/painelLattes/mapa.

CONSERVATION INTERNATIONAL, FUndAÇão SOS MATA AtlâNTICA, FundaÇão Biodiversitas, InSTITUTO DE Pesquisas ECológicas, Secretária do Meio Ambiente do Estado DE SÃo PaUlo AND SEMAD/INSTITUTO EstaduAl DE Florestas-MG. 2000. Avaliação e ações prioritárias para a conservação da biodiversidade da Mata Atlântica e Campos Sulinos, Brasília: MMA/SBF, 40 p.

Conte CE AND RossA-Feres DC. 2006. Diversidade e ocorrência temporal da anurofauna (Amphibia, Anura) em São José dos Pinhais, Paraná, Brasil. Rev Bras Zool 23: 162-175.

Crist TO, Veech JA, Gering JC AND Summerville KS. 2003. Partitioning species diversity across landscapes and regions: A hierarchical analysis of $\alpha, \beta$, and $\gamma$ diversity. Am Nat 162: 734-743.

DAVIDSON C AND KNAPP RA. 2007. Multiple stressors and amphibian declines: dual impacts of pesticides and fish on yellow-legged frogs. Ecol Appl 17: 587-597.

DinIZ-FILHO JAF, BINI LM, PINTO MP, RANGEL TFLVB, Carvalho P, Vieira SL and Bastos RP. 2007. Conservation biogeography of anurans in Brazilian Cerrado. Biodivers Conserv 16: 997-1008.

DIXO M AND VERDADE VK. 2006. Leaf litter herpetofauna of the Reserva Florestal de Morro Grande, Cotia (SP). Biota Neotrop 6: 1-20.

Eterovick PC, CARnaval ACOQ, Borges-Nojosa DM, Silvano DL, SEgalla MV and SAzIMA I. 2005. An overview of amphibian declines in Brazil with new records from Serra do Cipó, State of Minas Gerais. Biotropica 37: 166-179.

FAZEY I, FISCHER J AND LINDENMAYER DB. 2005. Who does all the research in conservation biology? Biodiv Conserv 14: 917-934. 
Fontanello D AND Ferreira CM. 2007. Histórico da Ranicultura Nacional. Available at: http://www. aquicultura.br/historico.htm.

Frost DR. 2014. Amphibian Species of the World: an online reference, version 6.0. Avalaible at: http://research.amnh. org/vz/herpetology/amphibia/.

GiOvANELli JGR, HADDAD CFB AND ALEXANDRINO J. 2008. Predicting the potential distribution of the alien invasive American bullfrog (Lithobates catesbeianus) in Brazil. Biol Invas 10: 585-590.

GotelLi NJ AND ENTSMINGER GL. 2005. EcoSim: Null models software for ecology, version 7.72, Acquired Intelligence Inc. and Kesey-Bear. Avalaible at: http://homepages. together.net/ gentsmin/ecosim.htm.

Gower DJ AND WILKInSON M. 2005. Conservation Biology of Caecilian Amphibians. Conserv Biol 19: 45-55.

Guix JC, Montori A, Llorente GA, CARretero MA AND SANTOS X. 1998. Natural history and conservation of bufonids in four Atlantic rainforest areas of Southerastern Brazil. Herpetol Nat Hist 6: 1-12.

Haddad CFB, Toledo LF AND Prado C. 2008. Anfíbios da Mata Atlântica, $1^{\text {a }}$ ed., São Paulo: Editora Neotropica, 244 p.

HALLIDAY TR. 2008. Why amphibians are important. Int Zoo Yearb 42: 7-14.

Hero JM ET AL. 2006. Overview of the conservation status of Australian Frogs. Pac Conserv Biol 12: 313-320.

Heyer WR, Rand AS, Cruz CAG AND Peixoto OL. 1988. Decimations, extinctions, and colonizations of frog populations in southeast Brazil and their evolutionary implications. Biotropica 20: 230-235.

Houlahan JE, Findlay CS, SCHMIDT BR, MEYer AH AND KUZMIN SL. 2000. Quantitative evidence for global amphibian population declines. Nature 404: 752-755.

HURLBERT AH AND JETZ W. 2007. Species richness, hotspots, and the scale dependence of range maps in ecology and conservation. Proc Natl Acad Sci USA 104: 13384-13389.

IBGE. 2004. Mapa da vegetação do Brasil e Mapa de Biomas do Brasil. Available at: http://www.ibge.gov.br.

IUCN. 2001. IUCN Red List Categories and Criteria, version 3.1. Gland, Switzerland and Cambridge, U.K.: Species Survival Commission, World Conservation Union, 32 p.

IUCN, CONSERVATION INTERNATIONAL AND NATURESERVE. 2006. Global Amphibian Assessment. Available at: http:// www.globalamphibians.org.

IUCN. 2012. IUCN Red List of Threatened Species, version 2012.1. Available at: http://www.iucnredlist.org.

Izecksohn E AND CARvalho-E-Silva SP. 2001. Anfíbios do município do Rio de Janeiro, $1^{\mathrm{a}}$ ed., Rio de Janeiro: Editora UFRJ, 148 p.

JUNCÁ FA. 2001. Declínio mundial das populações de anfíbios. Sitientibus Sér Ci Biol 1: 84-87.

KING DA. 2004. The scientific impact of nations. Nature 430: 311-316.

KovaCH WL. 2004. MVSP: Multivariate Statistical Package, version 3.13m. Available at: http://www.kovcomp.co.uk/ mvsp/.
LAWLER JJ ET AL. 2006. Conservation science: a 20-year report card. Front Ecol Environ 4: 473-480.

LEBBoroni M, RicCHIARDINO G, BELLAVITA M AND CHELAZZI G. 2006. Potential use of anurans as indicators of biological quality in upstreams of central Italy. Amph-Rept 27: 73-79.

Lowe S, Browne M, Boudjelas S and De Poorter M. 2000. 100 of the world's worst invasive alien species A selection from the global invasive species database. Auckland: School of Geography and Environmental Sciences, University of Auckland, 12 p.

Loyola R, Becker CG, Kubota U, Haddad CFB, FonsecA CR AND LEWINSOHN TM. 2008. Hung out to dry: choice of priority ecoregions for conserving threatened Neotropical anurans depends on life-history traits. PLoS ONE 3: e2120.

MAGURRAN AE. 2004. Measuring biological diversity, $2^{\text {nd }}$ ed., Oxford: Blackwell Publishing, 70 p.

Margules CR AND PRESSEy RL. 2000. Systematic Conservation Planning. Nature 405: 242-253.

MARGULES CR AND SARKAR S. 2007. Systematic Conservation Planning, $1^{\text {st }}$ ed., Cambridge: Cambridge University Press, $278 \mathrm{p}$.

MASSARANI L. 2013. Brazil's science investment reaches record high. Nature News (01 August 2013): 13495.

MCT. 2010. Plano de ação em ciência, tecnologia e inovação: Principais resultados e avanços, Brasília: Ministério da Ciência e Tecnologia, 168 p.

Morais AR, Siqueira MN, Lemes P, MACiEl NM, DE Marco JR P AND BRITO D. 2013. Unraveling the conservation status of Data Deficient species. Biol Conserv 166: 98-102.

NySTROM P, HANSSON J, MANSSON J, SUNDSTEDT M, RESLOW C AND Brostrom A. 2007. A documented amphibian decline over 40 years: Possible causes and implications for species recovery. Biol Conserv 138: 399-411.

OKSANEN J, Kindt R, LEgENDRE P, O'HARA RB, GAVIN L, Simpson GL, Solymos P, SteVEnS MH AND WAGNER H. 2009. Vegan: Community Ecology Package. R package version 1.15-4. Available at: http://CRAN.R-project.org/ package $=$ vegan.

Pimenta BVS, Haddad CFB, NAscimento LB, CRUZ CAG AND POMBAL JR JP. 2005. Comment on "status and trends of amphibian declines and extinctions worldwide". Science 309: 5743.

POMBAL JR JP AND HADDAD CFB. 1999. Frogs of the genus Paratelmatobius (Anura: Leptodactylidae) with descriptions of two new species. Copeia 4: 1014-1026.

R Development Core Team. 2009. R: A language and environment for statistical computing. Vienna: $\mathrm{R}$ Foundation for Statistical Computing. Available at: http:// www.R-project.org.

SARKAR S AND ILLOLDI-RANGEL P. 2010. Systematic conservation planning: an updated protocol. Nat Conservação 8: 19-26.

SCHIESARI L, GRILLITSCH B AND GRILLITSCH H. 2007. Biogeographic biases in research and their consequences for linking amphibian declines to pollution. Conserv Biol 21: 465-471. 
Segalla MV, Caramaschi U, Cruz CAG, Garcia PCA, GRANT T, HADDAD CFB AND LANGONE J. 2012. Brazilian amphibians - List of species, Sociedade Brasileira de Herpetologia. Available at: http://www.sbherpetologia. org.br.

SEWELL D AND GRIFFITHS RA. 2009. Can a single amphibian species be a good biodiversity indicator? Diversity 1: 102117.

Silva ET, RibeIRo-Filho OP AND FeIO RN. 2011. Predation of native anurans by invasive bullfrogs in southeastern Brazil: spatial variation and effect of microhabitat use by prey. South Am J Herpetol 6: 1-10.

Silvano DL and Segalla MV. 2005. Conservation of Brazilian Amphibians. Conserv Biol 19: 653-658.

Stuart SN, Chanson JS, Cox NA, Young BE, Rodrigues ASL, Fischman DL AND WALLER RW. 2004. Status and trends of amphibian declines and extinctions worldwide. Science 306: 1783-1786.

Toledo LF AND BATISTA RF. 2012. Integrative Study of Brazilian Anurans: Geographic Distribution, Size, Environment, Taxonomy, and Conservation. Biotropica 44: 785-792.
TRINDADE-FILHO J, CARVALHO RA, BRITO D AND LOYOLA RD. 2012. How does the inclusion of Data Deficient species change conservation priorities for amphibians in the Atlantic Forest? Biodivers Conserv 21: 2709-2718.

URBINA-CARDONA JN. 2008. Conservation of Neotropical herpetofauna: research trends and challenges. Trop Conserv Sci 1: 359-375.

VERDADE VK ET AL. 2012. A leap further: The Brazilian amphibian conservation action plan. Alytes 29: 27-42.

Weygold P. 1989. Changes in the composition of mountainstream frog communities in the Atlantic mountains of Brazil: frogs as indicators of environmental deteriorations? Stud Neotrop Fauna Environ 243: 249-255.

Young B ET AL. 2001. Population declines and priorities for Amphibian conservation in Latin America. Conserv Biol 15: $1213-1223$. 